\title{
ॠUSGS
}

science for a changing world

19

Prepared in cooperation with the New York State Department of Environmental Conservation

\section{Hydrogeology of Valley-Fill Aquifers and Adjacent Areas in Eastern Chemung County, New York}

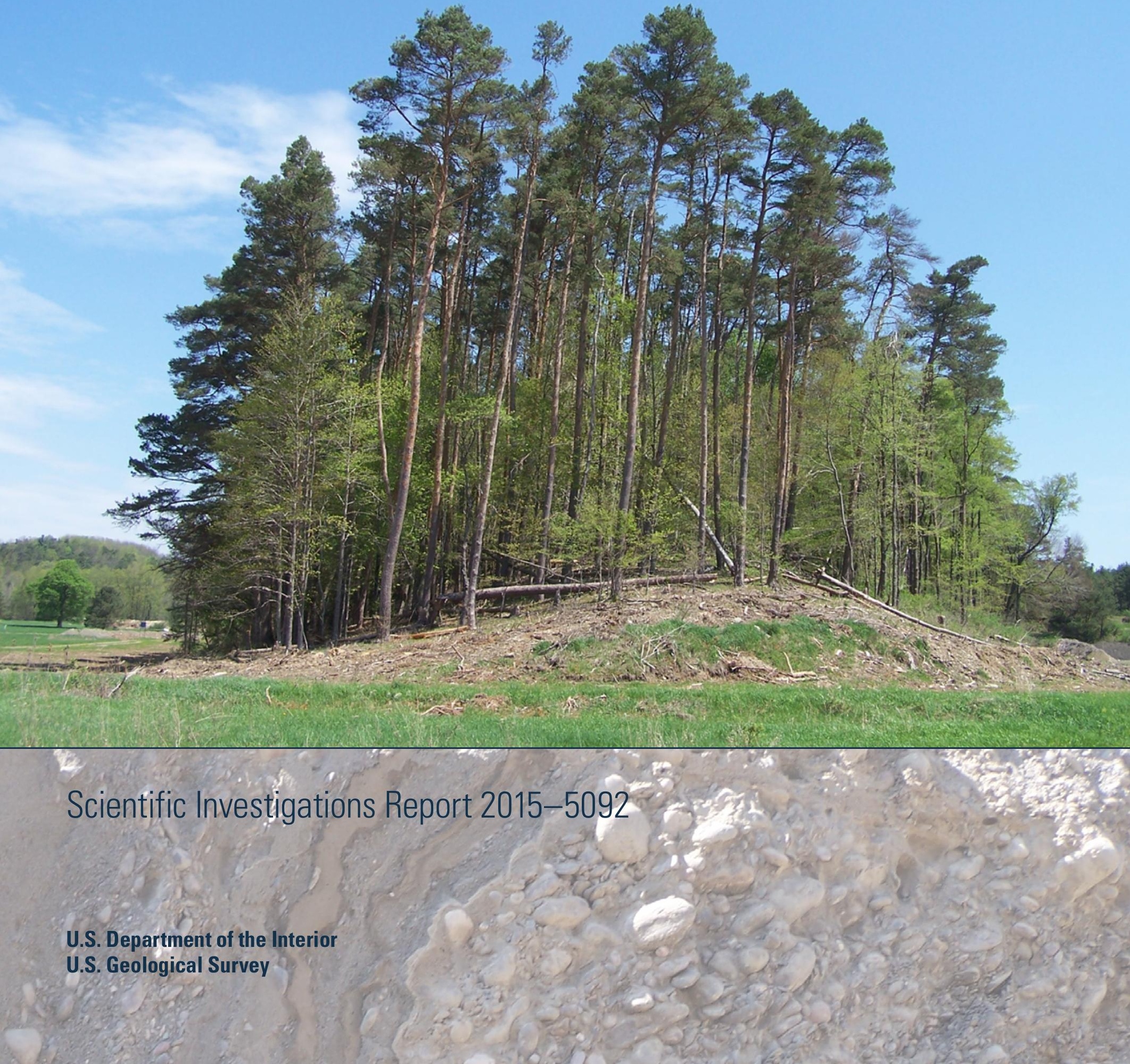


Cover. Esker sand and gravel deposit, looking northeast, Breesport, New York. 


\section{Hydrogeology of Valley-Fill Aquifers and Adjacent Areas in Eastern Chemung County, New York}

By Paul M. Heisig

Prepared in cooperation with the

New York State Department of Environmental Conservation

Scientific Investigations Report 2015-5092 


\title{
U.S. Department of the Interior SALLY JEWELL, Secretary
}

\section{U.S. Geological Survey Suzette M. Kimball, Acting Director}

\author{
U.S. Geological Survey, Reston, Virginia: 2015
}

For more information on the USGS - the Federal source for science about the Earth, its natural and living resources, natural hazards, and the environment-visit http://www.usgs.gov/ or call 1-888-ASK-USGS.

For an overview of USGS information products, including maps, imagery, and publications, visit http://www.usgs.gov/pubprod/.

Any use of trade, firm, or product names is for descriptive purposes only and does not imply endorsement by the U.S. Government.

Although this information product, for the most part, is in the public domain, it also may contain copyrighted materials as noted in the text. Permission to reproduce copyrighted items must be secured from the copyright owner.

Suggested citation:

Heisig, P.M., 2015, Hydrogeology of valley-fill aquifers and adjacent areas in eastern Chemung County, New York: U.S. Geological Survey Scientific Investigations Report 2015-5092, 19 p. plus appendix and 1 pl., http://dx.doi.org/10.3133/sir20155092.

ISSN 2328-0328 (online) 


\section{Acknowledgments}

The author expresses sincere thanks to Thomas Kump, director of environmental health services, and Lindsey Brown, senior environmental health specialist, of the Chemung County Health Department for providing water-supply information and facilitating site visits. Thanks are also extended to Allan Randall and Dennis Low of the U.S. Geological Survey for colleague reviews. Special thanks to Allan Randall for extended followup discussions of regional hydrogeology. 



\section{Contents}

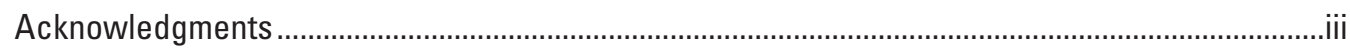

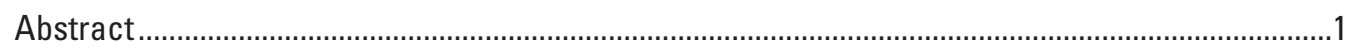

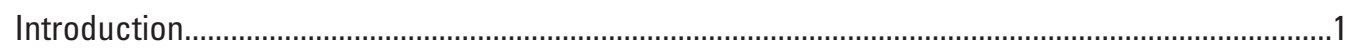

Purpose and Scope .....................................................................................................

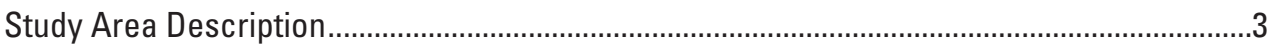

Current [2014] Groundwater Use and Sources ......................................................................

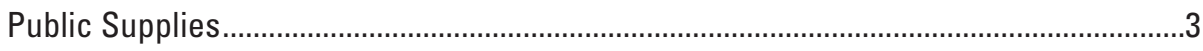

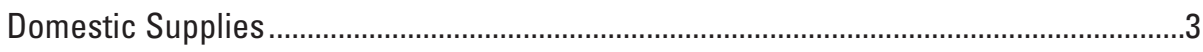

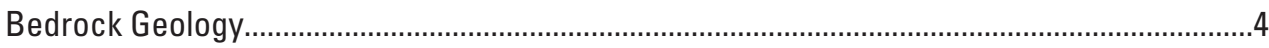

Previous Investigations of Glacial Deposits and Valley-Fill Aquifers in the Region.................. 4

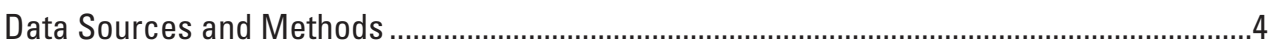

Distribution and Origin of Glacial and Postglacial Deposits............................................................

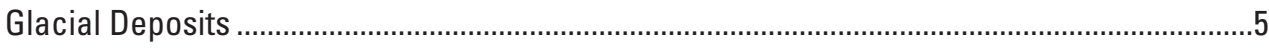

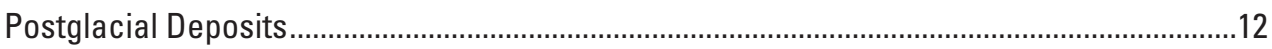

Groundwater-Resource Potential of Valley-Fill Aquifers in the Study Area .................................12

Sources of Groundwater and Groundwater Flow ..................................................................14

Considerations for Aquifer Protection ................................................................................

Upland Watersheds That Contribute Water to Valley-Fill Aquifers..........................................15

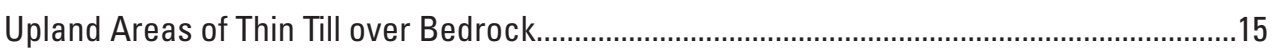

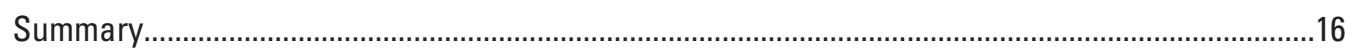

References Cited.................................................................................................................

Appendix 1. Well Data for Eastern Chemung County, New York ....................................................19

\section{Plate}

1. Hydrogeology of valley-fill aquifers and adjacent areas in eastern Chemung County, New York [http://dx.doi.org/10.3133/sir20155092]

\section{Figures}

1. Map showing eastern Chemung County, New York, including study area, topography, hydrography, and political features

2. Hydrogeologic cross section $A-A^{\prime}$, Chemung River valley west of Chemung, New York

3. Hydrogeologic cross section $B-B^{\prime}$, Chemung River valley west of Lowman, New York

4. Hydrogeologic cross section $C-C^{\prime}$, Wynkoop Creek valley north of Beantown, New York

5. Hydrogeologic cross section $D-D^{\prime}$, Newtown Creek valley at Erin, New York ................9 
6. Hydrogeologic cross section $E-E^{\prime}$, Newtown Creek valley at Breesport, New York .....10

7. Map showing extent of valley-fill aquifers, confining units, and aquifer well-yield potential, eastern Chemung County, New York .............................................................13

8. Conceptual block diagram of groundwater flow in a valley underlain by fine-grained lacustrine deposits in the dissected Appalachian Plateau area of south-central New York State.

\section{Conversion Factors}

Inch/Pound to International System of Units

\begin{tabular}{lcl}
\hline \multicolumn{1}{c}{ Multiply } & By & \multicolumn{1}{c}{ To obtain } \\
\hline foot $(\mathrm{ft})$ & Length & \\
mile $(\mathrm{mi})$ & 0.3048 & meter $(\mathrm{m})$ \\
& 1.609 & kilometer $(\mathrm{km})$ \\
\hline square mile $\left(\mathrm{mi}^{2}\right)$ & Area & \\
square mile $\left(\mathrm{mi}^{2}\right)$ & 259.0 & hectare $(\mathrm{ha})$ \\
\hline & 2.590 & square kilometer $\left(\mathrm{km}^{2}\right)$ \\
\hline gallon per minute $(\mathrm{gal} / \mathrm{min})$ & Flow rate & \\
\hline & 0.06309 & liter per second $(\mathrm{L} / \mathrm{s})$ \\
\hline foot per mile $(\mathrm{ft} / \mathrm{mi})$ & Hydraulic gradient & \\
\hline
\end{tabular}

\section{Datum}

Vertical coordinate information is referenced to the North American Vertical Datum of 1988 (NAVD 88).

Horizontal coordinate information is referenced to the North American Datum of 1983 (NAD 83). Elevation, as used in this report, refers to distance above the vertical datum.

\section{Abbreviations}

lidar light detection and ranging

NWIS National Water Information System

NYSDEC New York State Department of Environmental Conservation

USGS U.S. Geological Survey 


\title{
Hydrogeology of Valley-Fill Aquifers and Adjacent Areas in Eastern Chemung County, New York
}

\author{
By Paul M. Heisig
}

\section{Abstract}

The extent, hydrogeologic framework, and potential well yields of valley-fill aquifers within a 151-square-mile area of eastern Chemung County, New York, were investigated, and the upland distribution of till thickness over bedrock was characterized. The hydrogeologic framework of these valleyfill aquifers was interpreted from multiple sources of surficial and subsurface data and an interpretation of the origin of the glacial deposits, particularly during retreat of glacial ice from the region. Potential yields of screened wells are based on the hydrogeologic framework interpretation and existing wellyield data, most of which are from wells finished with openended well casing.

Water-resource potential is greatest within saturated sand and gravel in the Chemung River valley (nearly 1 mile wide), especially where induced infiltration of additional water from the Chemung River is possible. The second most favorable area is the Newtown Creek valley at the confluence of Newtown Creek with North Branch Newtown Creek east of Horseheads, N.Y. Extensive sand and gravel deposits within the Breesport, N.Y., area are largely unsaturated but may have greater saturation along the east side of Jackson Creek immediately north of Breesport. Till deposits confine sand and gravel along Newtown Creek at Erin, N.Y., and along much of the upper reach of North Branch Newtown Creek; this confining unit may limit recharge and potential well yield. The north-south oriented valleys of Baldwin and Wynkoop Creeks end at notched divides that imply input of glacial meltwater and limited sediment from outside of the present watersheds. These two valleys are relatively narrow but contain variably sorted sand and gravel, which, in places, may be capable of supplying modest-size community water systems.

\section{Introduction}

In 2013, the U.S. Geological Survey (USGS), in cooperation with the New York State Department of Environmental Conservation (NYSDEC), began an appraisal of the valley-fill aquifers within a 151-square-mile $\left(\mathrm{mi}^{2}\right)$ area in eastern Chemung County, New York. The area includes an 8-mile (mi) reach of the Chemung River valley between
Lowman and Chemung, N.Y., and the river valley's local watershed area, including major tributaries Baldwin Creek and Wynkoop Creek. Newtown Creek and its watershed area east of Horseheads, N.Y. (fig. 1), is also included in the study area. The study area fills a gap in previous aquifer mapping work between the Elmira area (Miller and others, 1982) and the Waverly-Sayre area (Reynolds, 2003).

This study is a continuation of a series of hydrogeologic appraisals since 1980 in cooperation with the NYSDEC through the Federal-State Aquifer Mapping Program. These reports provide a foundation for wellhead protection programs, water-resource management and planning decisions, and groundwater remediation in Upstate New York.

The study area has undergone natural-gas resource development with conventional gas wells and is underlain by the Marcellus and Utica Shales, which are unconventional sources of natural gas. Therefore, aquifer mapping and an understanding of sources of water that replenish the aquifer, along with current [2014] water-resource use in the valleys and upland areas, was warranted for management and protection of water resources.

\section{Purpose and Scope}

This report summarizes the hydrogeology of the valleyfill aquifers in an 8-mi reach of the Chemung River valley and the valleys of Baldwin, Wynkoop, and Newtown Creeks in eastern Chemung County (fig. 1), as well as the distribution of thin and thick till in their surrounding upland watershed areas. An interactive map plate (plate 1) was constructed with several layers of information, including the following:

- extent of the valley-fill aquifer system

- surficial geology

- extent of lacustrine and till confining units

- locations of hydrogeologic sections

- well locations

- high-resolution light detection and ranging (lidar) hillshade imagery of land surface

- 1:24,000-scale topographic base map 


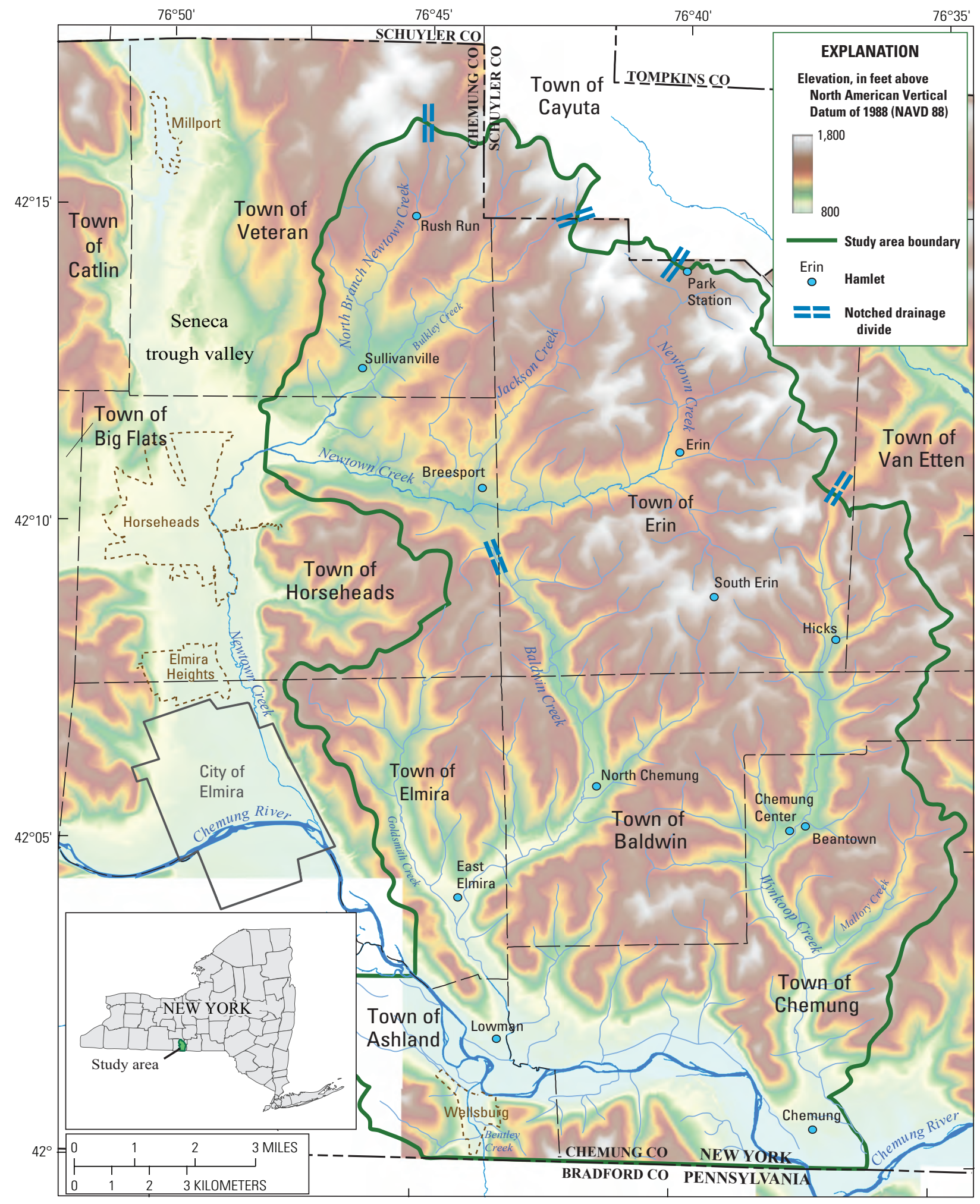

Elevation from Federal Emergency Management Agency, lidar survey, 2008

Universal Transverse Mercator projection, zone 18

North American Datum of 1983

Figure 1. Eastern Chemung County, New York, including study area, topography, hydrography, and political features. 
The report includes descriptions of the study area, five hydrogeologic sections, water-resource potential within the study area, and a conceptual diagram of groundwater flow. Previous work and current [2014] water use in the area are summarized, and a rationale for the distribution and groundwater-resource potential of valley-fill deposits depicted on the plate and the hydrogeologic sections is provided. Groundwater flow within bedrock and glacial deposits is outlined, followed by considerations for groundwater-resource protection. The well data are also provided (appendix 1).

\section{Study Area Description}

The study area $\left(151 \mathrm{mi}^{2}\right)$ covers much of the eastern half of Chemung County, including most of the Towns of Ashland, Baldwin, Chemung, Elmira, and Erin, N.Y., and parts of the Towns of Horseheads, Van Etten, and Veteran, N.Y. (fig. 1). The population of the study area is about 9,500, estimated from ZIP Code population data (USA.com, 2012).

The study area lies within the northern dissected Appalachian Plateau, wherein nearly flat-lying to gently dipping shale, siltstone, and sandstone bedrock forms gently rounded hilltops separated by deeply incised, steep-walled valleys (Williams and others, 1909). Hilltops range between 1,400 and 1,600 feet (ft) in elevation over much of the area but exceed 1,700 $\mathrm{ft}$ in elevation in the southwestern, northern, and northeastern edges of the study area. The lowest hilltops (1,300 to 1,400 ft; fig. 1) are near Sullivanville, N.Y., in the west-northwestern part of the study area. The floors of the largest valleys range from about $1,200 \mathrm{ft}$ in elevation to about $800 \mathrm{ft}$ where the Chemung River exits the study area. The Chemung River valley is about 1 mi wide within the study area. The valley floors of the major tributary valleys (fig. 1) are typically between 0.1 and 0.3 mi wide. The Newtown Creek valley is almost $0.5 \mathrm{mi}$ wide at Breesport, N.Y., and immediately downvalley of the confluence of Newtown Creek with North Branch Newtown Creek.

The Chemung River drains the region and has a watershed area of 2,510 $\mathrm{mi}^{2}$ at Chemung. All major streams in the study area are tributaries of the Chemung River. Newtown Creek flows west and then south through part of the Seneca trough valley (Williams and others, 1909; Gillespie, 1980), a wide, deep, glacially eroded valley that extends south from Seneca Lake (fig. 1). Newtown Creek joins the Chemung River at Elmira, upstream from the Chemung River portion of the study area. Baldwin and Wynkoop Creeks flow south and join the Chemung River within the study area.

Glaciation has modified the form of watershed boundaries in the study area and region. Notched drainage divides (drainage divides within valleys rather than on upland hilltops and ridges) or "notches" are common along the northern or northeastern edges of all major tributary watersheds (fig. 1). These notches were preferentially eroded by successive glaciations and also briefly conveyed meltwater from glacial ice that abutted the northern or northeastern sides of the divide. The notches are typically narrow and flat bottomed and may contain coarse stratified sediments (such as the headwater notches of Baldwin Creek and North Branch Newtown Creek; fig. 1, plate 1).

\section{Current [2014] Groundwater Use and Sources}

As of 2014, groundwater is the sole source of water supply for about 93 percent of the study-area population, the exception being the Village of Wellsburg, N.Y., which is served by a blend of surface water and groundwater sources (Elmira Water Board, 2015). Community water-supply systems serve about 18 percent of the population. The use of aquifers consisting of sand and gravel for water supply is largely limited to the valley fill, whereas the underlying fractured-bedrock aquifer is utilized in the uplands and headwater valleys.

\section{Public Supplies}

There are 44 public-water supplies that utilize groundwater within the study area-10 community supplies and 34 small noncommunity supplies (U.S. Environmental Protection Agency, [n.d.]). The community supplies serve about 1,100 people, primarily mobile home parks. Most supplies are modest - the highest reported well yields are between 50 and 170 gallons per minute (gal/min). The Village of Wellsburg historically derived its public supply from a shallow unconfined sand and gravel aquifer beneath the village but has since abandoned that source and currently [2014] purchases water from the City of Elmira.

\section{Domestic Supplies}

Well-permit data from NYSDEC indicate that most new domestic wells that are drilled in upland areas tap the fractured-bedrock aquifer. Historically, domestic water needs in upland areas were supplied by dug wells and springs fed by shallow groundwater from local permeable zones in glacial till. Wells completed in the Chemung River valley and major tributary valleys may tap unconfined sand and gravel or thin, typically confined sand and gravel just above the bedrock or a confined fractured-bedrock aquifer within the uppermost few feet of the bedrock. Overall, NYSDEC well records indicate that 77 percent of domestic wells drilled since 2000 were completed in bedrock. Many areas in the valley bottom of the Chemung River valley and major tributary valleys have little new development because most land continues to be used for agriculture.

Well logs from the USGS National Water Information System (NWIS) database (U.S. Geological Survey, 2001) and from the NYSDEC well-permit program indicate that most domestic wells in valley settings are (1) completed with openended casing (no well screen) in sand and gravel deposits or are (2) cased to bedrock and completed as open-hole 
bedrock wells. Yields from most wells with open-end casing are sufficient to meet the owner's needs but are only a small fraction of what could have been obtained by placing a well screen within the water-yielding sand and gravel.

\section{Bedrock Geology}

Bedrock in the study area consists chiefly of siltstones, shales, and sandstones. The Marcellus and Utica Shales are natural gas-bearing formations that underlie the study area. The Marcellus Shale is present at depths ranging from about 4,500 ft at the New York-Pennsylvania border to about $3,000 \mathrm{ft}$ just north of the study area (New York State Museum, 2014). The Utica Shale is present at depths ranging from about 9,500 ft at the New York-Pennsylvania border to about $7,500 \mathrm{ft}$ at the northern boundary of the study area (Marcellus Center for Outreach and Research, 2015).

The most near-surface rocks are the West Falls Group of Late Devonian age (Rickard and Fisher, 1970; McGhee and Sutton, 1985). These bedrock units dip gently to the south (10 to 40 feet per mile [ft/mi]; Coates, 1981), which results in the exposure of the oldest units in the north and progressively younger units to the south. Gentle east- and northeast-trending folds are also present, with similar dips (Coates, 1981; Williams and others, 1909; Wedel, 1932).

Lineaments, which are linear topographic features, are common within the study area. These features presumably represent less competent bedrock characterized by either increased fracture density or faulting (Isachsen and McKendree, 1977; Jacobi, 2002; Lash and others, 2004). Many main and tributary valley segments reflect faults or regional joint sets. Intersections of lineaments may be favorable for groundwater resources from bedrock. Bedrock groundwater resources are also more sustainable if the bedrock is overlain by saturated, permeable glacial deposits.

\section{Previous Investigations of Glacial Deposits and Valley-Fill Aquifers in the Region}

Pertinent previous work in and around the study area includes surficial-deposit maps and hydrogeologic studies that report subsurface geologic information, well characteristics, and characterization of aquifers and the hydrologic system in general. Surficial geologic information is reported in the Chemung County soil survey (Pearson and others, 1973; U.S. Department of Agriculture, 2008), which describes sediment types or parent materials (unconsolidated sediments) upon which different soils develop, and also in regional surficial geologic mapping by Williams and others (1909), Denny and Lyford (1963), Gillespie (1980), and Muller and Cadwell (1986). USGS aquifer mapping and hydrogeology studies have also been completed immediately west (Miller and others, 1982) and east (Reynolds, 2003) of the study area. Well data have been compiled in a county groundwaterresource study (Wetterhall, 1959) and in a regional effort by
Randall (1972). Hydrogeologic investigations at landfills in the study area (Chemung County landfill [Barton and Loguidice, D.P.C., 2014] and Jilson's landfill [YEC, Inc., 1991]) provide site-specific information within the Chemung River valley.

Aquifer types and thicknesses were estimated in the major valleys of the area by Hollyday (1969) and by MacNish and Randall (1982). Randall (2001) also described and conceptualized the hydrogeologic framework of aquifers in unconsolidated deposits of stratified glacial sediment (termed "drift") throughout the glaciated northeastern United States. The importance of upland sources of recharge to these aquifers in valleys in the Appalachian Plateau of New York and adjacent Pennsylvania has been reported (Crain, 1966; Randall, 1978; Morrissey and others, 1988; Williams, 1991; Heisig, 1999). Upland sources include runoff and groundwater flow from adjacent unchanneled hillsides and infiltration of water from tributary streams as they enter valleys across alluvial fan deposits.

\section{Data Sources and Methods}

Surficial geology, subsurface sand and gravel deposits, and boundaries of the valley-fill aquifer system were delineated with well data, Soil Survey Geographic (SSURGO) digital data (U.S. Department of Agriculture, 2008), lidar imagery, and geologic mapping by previous workers. Sources of well data include previous USGS groundwater studies (Wetterhall, 1959; Randall, 1972), the USGS NWIS (U.S. Geological Survey, 2001), well records obtained from the NYSDEC Water Well Drillers Registration Program, and New York State Department of Transportation test boring data. Records collected for this study have been entered into the USGS NWIS database (http://waterdata.usgs.gov/nwis/; U.S. Geological Survey, 2001).

Aquifer delineation includes areas of saturated stratified drift in valleys as well as adjacent areas of stratified drift along valley walls that are thinly saturated but may readily contribute recharge to the saturated valley-floor deposits (plate 1). Areas in or adjacent to valley bottoms that are mapped as gravelly till in the county soil survey, or as a mix of till and gravel soils, were included within the aquifer extent if surface morphology in lidar imagery was similar to that of ice-contact deposits. Stratified-drift deposits that are potential sources of groundwater supply extend beyond surficial stratified deposits in some valley areas where till overlies sand and gravel. Till may have been deposited directly over older permeable sediments during glaciation or may have slumped over outwash deposits from unstable valley wall positions after glaciation (Denny and Lyford, 1963, p. 15-20; King and Coates, 1973).

Alluvium (stream and river deposits) generally ranges from a few feet thick in upland tributary valleys to as much as 15 to $18 \mathrm{ft}$ thick in the Chemung River valley and typically is coarsest at the bottom of the deposit. Alluvium in upland 
valleys and hollows is delineated as part of the aquifer if well logs indicate, or it can be inferred, that older sand and gravel underlies the alluvium and the valley bottom is at least $250 \mathrm{ft}$ wide. Alluvial deposits above $1,300 \mathrm{ft}$ elevation are typically underlain by till and not mapped as aquifer material. Alluvial fan deposits are common stratified postglacial deposits in the study area and are included as part of the aquifer extent in valleys that contain underlying aquifer material.

\section{Distribution and Origin of Glacial and Postglacial Deposits}

The surficial and subsurface distribution of glacial and postglacial deposits of Pleistocene and Holocene age, respectively, are depicted on plate 1 and in five hydrogeologic sections that cross valleys of the study area (figs. 2-6).

\section{Glacial Deposits}

Glacial ice completely covered the region and the direction of movement was generally southwestward (Denny and Lyford, 1963). During this time, till was deposited over much of the study area. Till is the dominant glacial deposit in the uplands but is typically thin on hilltops and on upper slopes that faced flowing ice (plate 1). Till is typically thickest (as much as $120 \mathrm{ft}$ ) and most widespread (1) in the northwestern part of the study area, which is adjacent to the Valley Heads moraine north of Horseheads (Fairchild, 1932), and (2) on lower hillsides in the lee of ice-flow direction ("till shadows," as described by Coates, 1966). Till shadows are present along the north side of the approximately eastwest oriented reach of the Chemung River valley (plate 1). Geologic section $A-A^{\prime}$ near Chemung (fig. 2) depicts till as the primary valley-fill deposit within the northern half of the section with younger ice-contact deposits sitting atop the till.

As the ice retreated north, ice downwasting and retreat likely occurred first in upland areas where the ice was thinnest and the underlying topography was roughest. Loss of regional flow across the uplands shifted active ice movement to the largest valleys. Ice was likely most active in northsouth oriented valleys parallel to the general direction of ice movement (Gillespie, 1980), such as the Seneca trough valley (fig. 1), which merges with the Chemung River valley at Elmira. Valley segments oriented east-west and with sharp turns provided resistance to ice flow that eventually led to stagnation of valley ice. The east-west oriented reaches of the Chemung River and Newtown Creek valleys in the study area (figs. 2, 3, and 5; plate 1) show evidence of ice stagnationesker segments are preserved and other ice-contact deposits are present (Williams and others, 1909).

Ice-contact deposits with numerous esker segments indicate that ice stagnated along most of the Chemung River valley reach within the study area. Ice-contact deposits appear midvalley about $1.5 \mathrm{mi}$ west of Lowman and continue, with numerous esker segments, along the north side of the valley for about 4 mi near the Chemung County landfill (fig. 3; plate 1). Additional limited meltwater and sediment from the Baldwin Creek drainage (discussed in the next paragraph) may have contributed to the ice-contact deposits in the area (fig. 1; plate 1). East of the Chemung County landfill, an extensive ice-contact deposit is present on the south side of the valley at the inside of a nearly 90 -degree bend in the river and extending to about $1 \mathrm{mi}$ west of the hamlet of Chemung (fig. 2; plate 1). This deposit likely occupied the width of the valley-well and test-boring logs indicate mostly till or ice-contact material (and only minor lacustrine sediments) beneath the present flood plain - and likely represents an ice marginal position. Somewhat later, a valley train of outwash was deposited downvalley from this area; Denny and Lyford (1963, plates 1 and 4) mapped remnants at 850-ft elevation 2 mi west of Chemung, at 830- to 820 -ft elevation southwest and south of Chemung, and at $800-\mathrm{ft}$ elevation in eastern Chemung County, all 25 to $30 \mathrm{ft}$ above the modern flood plain. Ice-contact deposits and outwash in this area and downvalley collectively ponded meltwater upvalley during continued glacial retreat and downwasting. Lacustrine fine sand, silt, and clay deposits up to $60 \mathrm{ft}$ thick are present in the few deep upvalley well logs (fig. 3; plate 1). Eventually, incision downvalley and deposition in the lake resulted in renewed deposition of outwash sand and gravel over the lacustrine deposits as the ice margin retreated upvalley. Most of these sediments were likely derived from meltwater drainage from the ice margin that deposited the Valley Heads moraine, north of Horseheads (Gillespie, 1980).

Ice retreat in upland areas contributed some meltwater to the Chemung River valley. The drainage area of tributary watersheds south of the Chemung River valley is relatively minor, but drainage area on the north side is about $80 \mathrm{mi}^{2}$, most of which is drained by Baldwin $\left(39.9 \mathrm{mi}^{2}\right)$ and Wynkoop $\left(35.4 \mathrm{mi}^{2}\right)$ Creeks. Additional temporary meltwater drainage from ice north of these watersheds is also indicated through notched (flat-bottomed) divides (fig. 1). Ice-contact deposits are present at land surface (plate 1) and in the subsurface at the Baldwin Creek notch (CM 359), and in the subsurface south of the Wynkoop Creek notch (wells CM2205, CM2207, CM2160, CM2156, CM 423, and CM2146). Downgradient from the notches, the floors of both valleys are underlain by as much as $45 \mathrm{ft}$ of variably silty sand and gravel (over till deposits and bedrock, and beneath alluvium). Gravelly till or ice-contact deposits also occur at regular intervals along the sides of the Baldwin Creek valley (Williams and others, 1909), with fewer occurrences in the Wynkoop Creek valley (fig. 4; plate 1). This difference in washed or stratified sediments indicates greater meltwater drainage through the Baldwin Creek valley during early ice retreat and downwasting than in the Wynkoop Creek valley, which is consistent with the mass of stratified deposits north of the Baldwin Creek notch in the Breesport area. 


\section{EXPLANATION FOR FIGURES 2-6}

[Figures 2-6 and plate 1, showing locations of cross sections from figures 2-6, are available separately at http://dx.doi.org/10.3133/sir20155092.]

\section{POSTGLACIAL (HOLOCENE AGE) DEPOSITS}

al

alf

alg

cf

Lf

w

OPEN WATER — Areas of open water such as rivers, lakes, large ponds, and reservoirs

\section{GLACIAL (PLEISTOCENE-AGE) DEPOSITS} deposits (outwash or ice-contact) that constitute the stratified-drift aquifer

CUT AND FILLED LANDS - Primarily constructed landforms such as dams, and railroad and highway grades

LANDFILLS - Active and inactive sites, limited to the Chemung River valley

ALLUVIUM - Postglacial river and stream flood-plain deposits typically less than 15 feet above the present-day stream level. Consists predominantly of stratified silt and clean to silty sand, commonly with some gravel at the base of the deposit. Thickness is as much as 15 to 20 feet in the Chemung River valley and large tributary valleys. Typically underlain by stratified glacial deposits in main valleys and by till in narrow upland valleys or hollows

ALLUVIAL FAN_-Fan-shaped accumulations of stratified silty sand and gravel, deposited by high-gradient tributary streams where they enter larger valleys. Commonly underlain by outwash or ice-contact sand and gravel derived, in part, from the upland drainage area associated with the alluvial fan. Alluvial fan deposits associated with present-day streams typically are graded to the current flood-plain altitude. Maximum thickness of alluvial fan deposits may approach 40 feet. Alluvial fan deposits have relatively high permeability but are thin and largely unsaturated; however, fan deposits are an important conduit for recharge to underlying glacial deposits. Infiltration of water from tributary streams that lose flow as they traverse fan deposits (Randall, 1978) are important sources of recharge to underlying glacial

ALLUVIAL GRAVEL - Late Pleistocene or early Holocene sand and gravel that, in places at least, underlies alluvium in the larger tributary valleys (Baldwin Creek, Wynkoop Creek) that received meltwater from outside their present-day watersheds through notched divides. Some of these deposits described as "dirty" gravels in drillers' logs. May include some older ice-contact sand and gravel, brief outwash inputs from the notched divides, and alluvial gravels from tributary watersheds

OUTWASH SAND AND GRAVEL-Stratified, well-sorted sand and gravel deposited by glacial meltwater streams as outwash terraces or deltas near the receding ice front and as valley-train outwash (originally spanning the width of the valley) away from ice-margin positions. Outwash in the study area is not extensive; terrace remnants are present in the Chemung River valley and in the Newtown Creek valley at Breesport. These deposits were associated with pauses in the retreat of active glacial ice that was discharging sediment-laden meltwater. Outwash sand and gravel deposits have very high permeability, but most within the study area have thin saturated thicknesses and therefore poor aquifer potential

ICE-CONTACT DEPOSITS - Stratified sand, gravel, and silt deposited by meltwater in a variety of environments in close proximity to glacial ice. May include kame terraces (along valley walls) in valley segments where active ice retreat was steady, or eskers, isolated kames, and kame fields (hummocky terrain) in valley areas of ice stagnation. Also includes subaquatic (lacustrine) fans in the subsurface immediately above bedrock in areas of active ice retreat. Till may be intermixed with some deposits because of localized slumping or mass movement from melting ice. Extreme variability in sorting, grain size, and thickness of individual beds. Moderate to high permeability, especially in coarse, well-sorted fractions. Deposits below the valley floor with favorable characteristics form localized unconfined or confined aquifers

LACUSTRINE SILT, CLAY, AND SAND (CONFINING UNITS)—Stratified lacustrine silt, clay, and sand units deposited in temporary lakes during glacial retreat

ic-tg ICE-CONTACT OR GRAVELLY TILL DEPOSITS - Areas with a mix of stratified sand and gravel and till. Where contiguous with other stratified deposits, considered within aquifer extent. Mapped as soils derived from gravelly tills or glaciofluvial sand and gravel in Soil Survey Geographic (SSURGO) data. Mapped as till, ice contact, or ice contact over till by previous workers. Highly variable sorting. Many of these deposits exhibit an uneven (hummocky) surface in light detection and ranging (lidar) imagery. Well logs indicate the range of mapping interpretations listed above

TILL - Thick, unsorted, unstratified mixture of clay, silt, sand, gravel, and boulders deposited beneath the ice as lodgment till during a glacial advance or at the edge of the ice sheet by melting ice as ablation till during a pause, or retreat, of the ice front. Thickness up to 120 feet. Very low permeability, but may yield adequate amounts of water for domestic use to large-diameter dug wells where sufficiently saturated or where gravelly zones of higher permeability exist

\section{OTHER FEATURES}

BEDROCK - Mostly Devonian-age shales, siltstones, and sandstones. Beds are gently folded and have a regional dip to the south from 10 to 40 feet per mile

WELL-Site name is assigned by the U.S. Geological Survey. CM, Chemung County; number following county abbreviation is the sequential well number

DEPTH TO WATER IN WELL, IN FEET—Measurements from well-log records range from 1940 to present. Primary sources are New York State Department of Environmental Conservation (since 2000) and U.S. Geological Survey. "ND" signifies no water-level measurement recorded

DEPOSIT BOUNDARIES—Dashed where inferred 


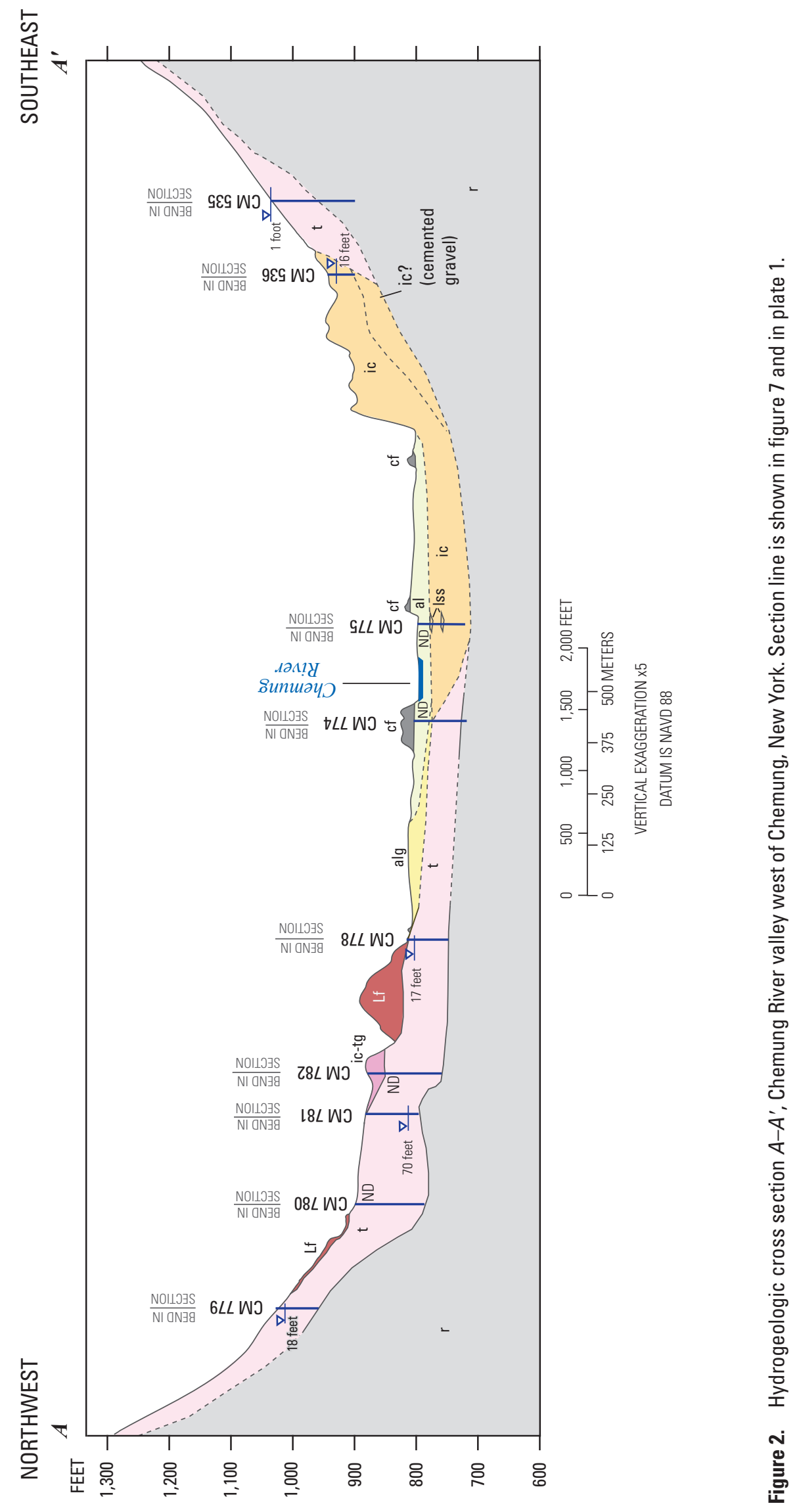


8 Hydrogeology of Valley-Fill Aquifers and Adjacent Areas in Eastern Chemung County, New York

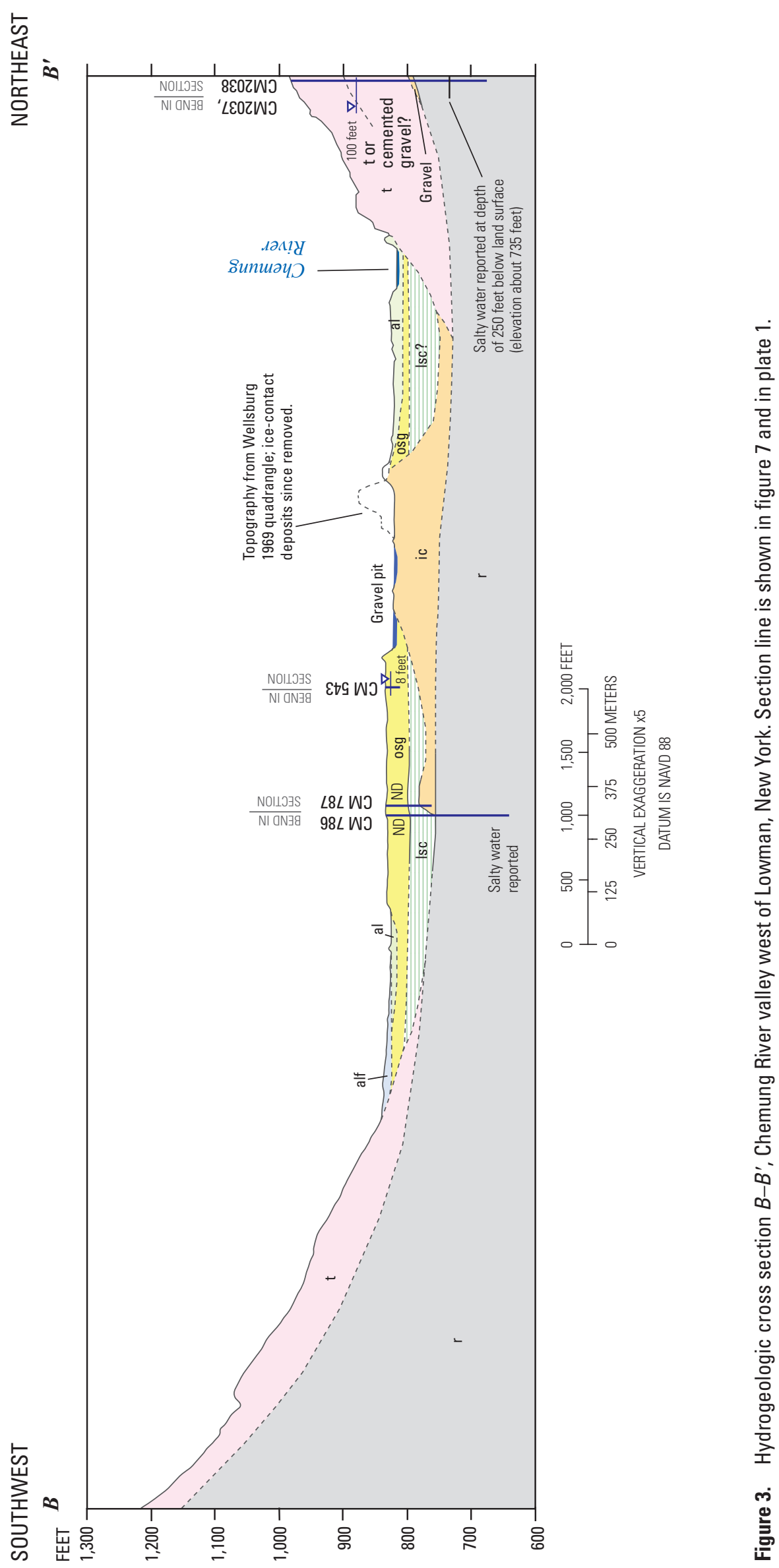




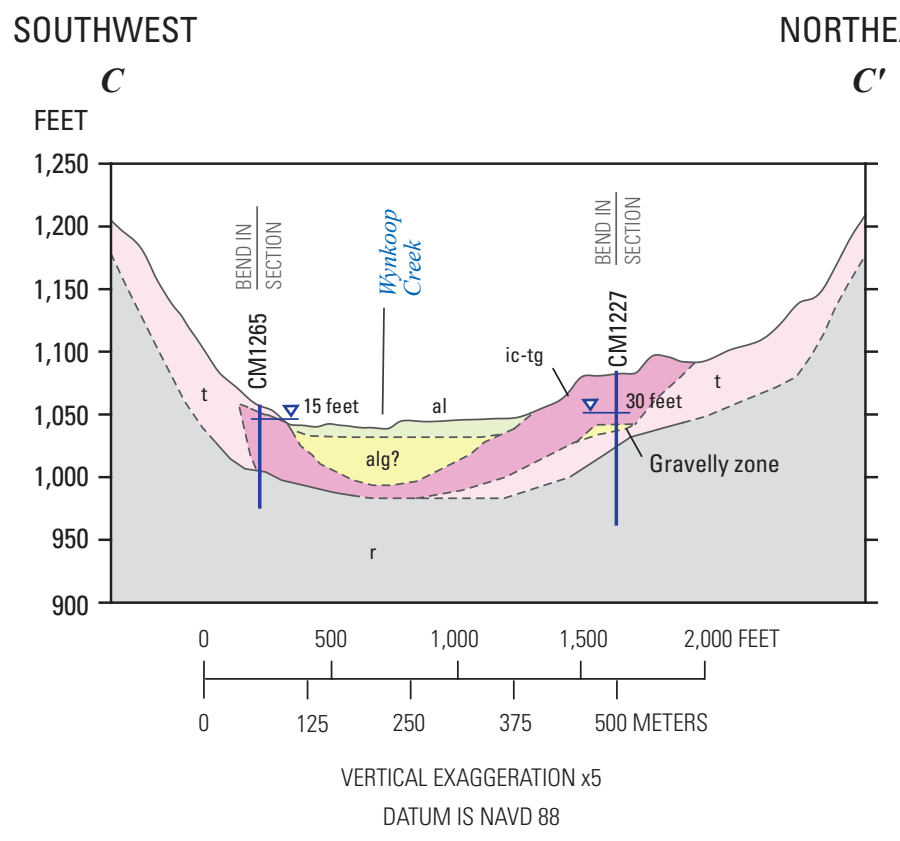

Figure 4. Hydrogeologic cross section $C-C^{\prime}$, Wynkoop Creek valley north of Beantown, New York. Section line is shown in figure 7 and in plate 1.

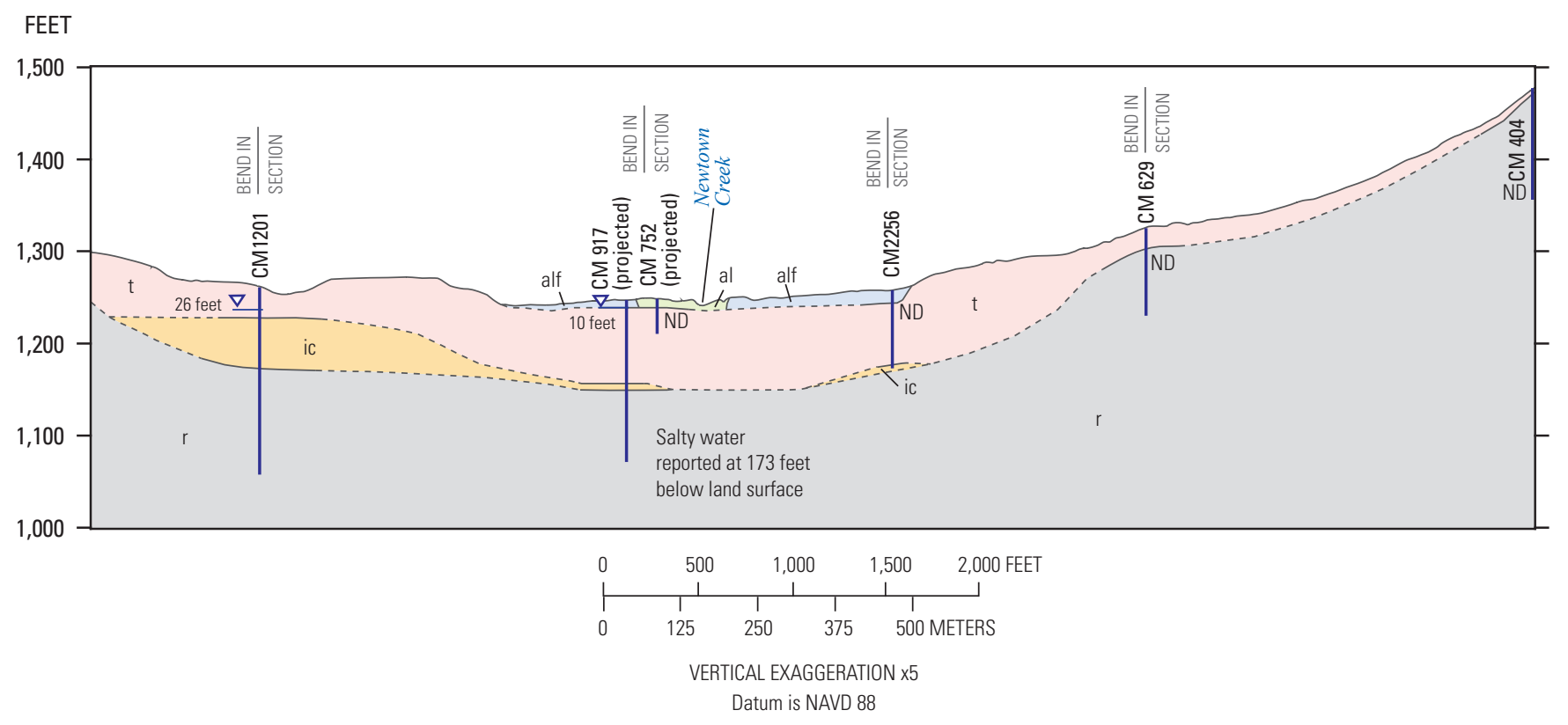

Figure 5. Hydrogeologic cross section $D-D^{\prime}$, Newtown Creek valley at Erin, New York. Section line is shown in figure 7 and in plate 1. 


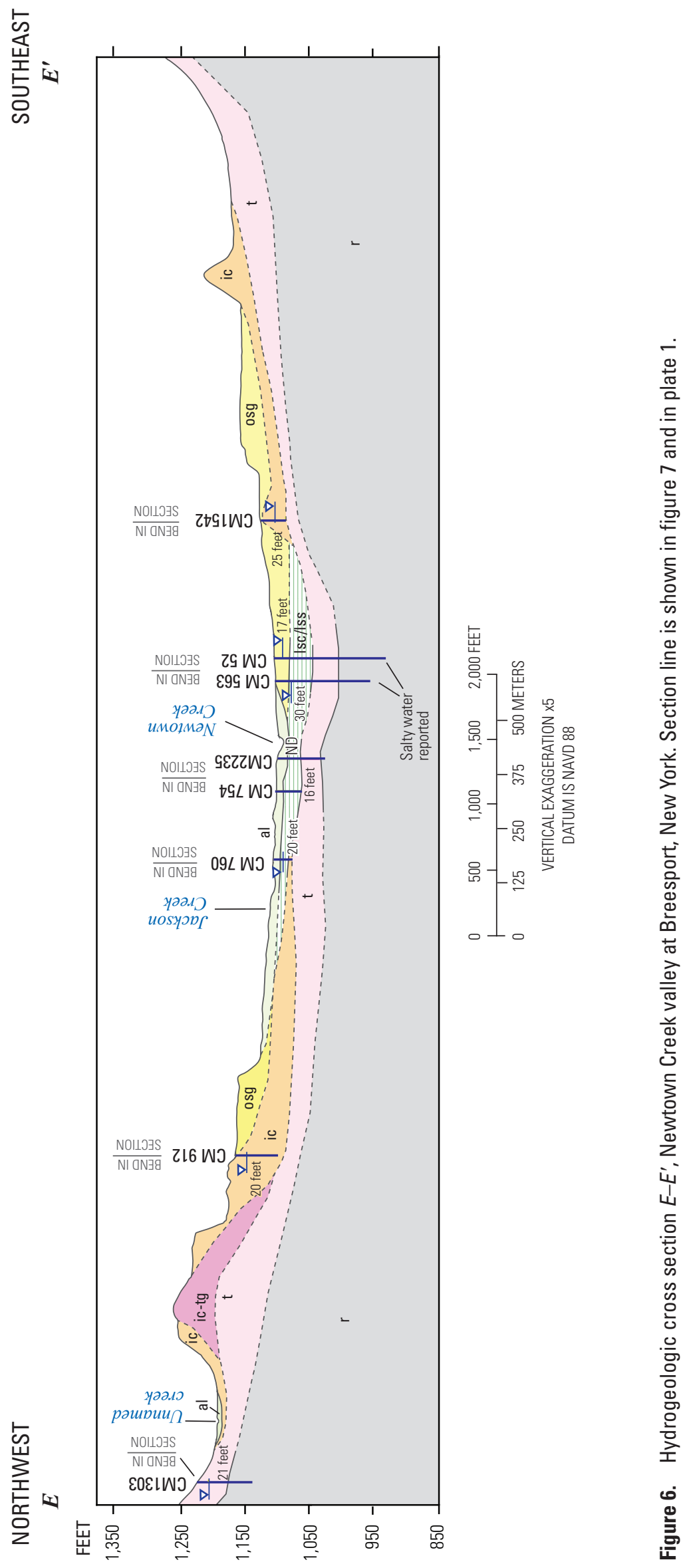


Newtown Creek drains the northern part of the study area. The main valley section of Newtown Creek, from Erin to where it enters the broad north-south Seneca trough valley at Horseheads (fig. 1), is oriented east-west with a nearly continuous escarpment on the south side; hilltop elevations range from 1,600 to 1,750 ft. At Breesport, the escarpment is breached by a deep notch (about 1,150 ft), henceforth referred to as the "Baldwin Creek notch," that is floored with alluvium and ice-contact material and forms the drainage divide between the Baldwin Creek and Newtown Creek watersheds. Newtown Creek watershed topography is more subdued on the north side of the valley than on the south side of the valley, but the watershed area is much larger on the north side (as in the Chemung River valley to the south). Headwater divides of Newtown Creek and two of its tributaries to the north and east also are deeply incised notches (fig. 1). The Newtown Creek notch (about 1,520 ft) likely received no out-of-basin meltwater because it is choked by mostly morainal deposits. It does have, however, an incised, well-developed flood plain despite a small drainage area. During deglaciation, the divides of North Branch Newtown Creek (about 1,510 ft) and Bulkley Creek (about 1,450 ft) received at least minor meltwater from the north, as indicated by local stratified material (Williams and others, 1909) at or south of the divides and steep slopes on the north sides of the divides.

The stratified-drift deposits in the east-west reach of the Newtown Creek valley, centered at Breesport (fig. 6; plate 1), were transported and deposited from meltwater that subsequently drained south through the Baldwin Creek notch. The presence of esker segments north of Breesport along Jackson Creek, a mass of ice-contact deposits at Breesport, and more esker segments and ice-contact material within and immediately north and south of Baldwin Creek notch (Williams and others, 1909; Denny and Lyford, 1963) indicate early southward meltwater flow within or beneath stagnant ice through the notch. Thinning ice at and near Breesport likely stagnated earlier than ice in other areas because southward movement was blocked by the escarpment and further constrained by high hills to the east. Ice in the Seneca trough valley to the west (at Horseheads) was still active, and an ice tongue occupied the lower Newtown Creek valley to just west of Breesport, effectively blocking westward drainage and ultimately depositing an outwash head at and slightly west of Breesport (Williams and others, 1909; Gillespie, 1980). Glacial deposits along the Newtown Creek valley walls west of Breesport are predominantly till, but with mixed ice-contact and gravelly till on valley walls near Breesport (plate 1).

At Breesport, the north side of the valley is a mix of till and ice-contact sand and gravel with mostly till and a veneer of sand and gravel east of Jackson Creek and with thicker sand and gravel over till on the west side of the creek (fig. 6). A possible esker trends north along the west side of Jackson Creek, and a well log near the junction of this feature with the main mass of ice-contact material indicates $62 \mathrm{ft}$ of sand and gravel (the greatest reported thickness in the Newtown
Creek drainage within the study area; well CM 912; plate 1; appendix 1).

Continued melting and retreat of ice north of Breesport and blockage of westward drainage by the ice tongue resulted in the formation of a small ice-marginal lake at Breesport that extended eastward to Erin (Williams and others, 1909) and whose level was controlled by the Baldwin Creek notch. Fine-grained sediment in meltwater from the ice tongue (and perhaps meltwater and runoff from north of Breesport) was deposited in the lake basin, followed by deposition of outwash sand and gravel that prograded across the lacustrine sediments from the same meltwater sources, completely filling the lake basin and grading to the outlet at the Baldwin Creek notch. The ice margin (outwash head) immediately west of Breesport is generally marked by ice-contact or gravelly till deposits along the Newtown Creek valley walls that transition eastward to outwash sand and gravel terrace remnants that grade from about 1,170 to $1,150 \mathrm{ft}$ at the notch. The notch elevation is not controlled by bedrock- a 49-ft deep well within the notch is completed in sand and gravel (well CM 359; plate 1; appendix 1).

Ice tongue retreat from the Breesport position to the main ice tongue in the Seneca trough valley opened a drainage pathway to the south that was at least $200 \mathrm{ft}$ lower than the Baldwin Creek notch - from 1,150 ft to about $950 \mathrm{ft}$ (where Newtown Creek enters the Seneca trough valley near Horseheads). Remnant ice, till, ice-contact, and outwash sediments at Breesport were incised by high flows from within the watershed, perhaps augmented by minor meltwater input across notched divides. Substantial downcutting at and immediately west of Breesport (a maximum of about $160 \mathrm{ft}$ ), accompanied by mass wasting (slumping) of adjacent slope material, resulted in fluvial gravel and outwash deposition in the Newtown Creek valley downstream from Breesport. The most favorable aquifer conditions in the lower reach of Newtown Creek are at the confluence with the North Branch Newtown Creek valley; water-yielding and locally continuous clean sand and gravel between about 30 and $50 \mathrm{ft}$ below land surface has been reported in well logs. This aquifer material is overlain by discontinuous, confining lacustrine deposits or nonconfining sand and gravel.

The large decrease in base level at Breesport left most of the outwash deposits above creek level and with thin saturated thicknesses (fig. 6). Incision rapidly decreases upvalley from Breesport. About $1 \mathrm{mi}$ east (upvalley) of the center of Breesport, the present-day flood plain is about $30 \mathrm{ft}$ lower than the adjacent outwash surface; $1.5 \mathrm{mi}$ farther upvalley, incision is negligible (fig. 5). The thickness of outwash/fluvial sand and gravel about $1 \mathrm{mi}$ upvalley from Breesport is about $30 \mathrm{ft}$, thinning and transitioning to about $15 \mathrm{ft}$ of gravelly alluvium about $0.75 \mathrm{mi}$ west of Erin. Saturation of these deposits is also likely minimal, either because of an adjacent low-elevation flood plain or because the deposit itself is thin.

Despite till blanketing both uplands and most valley walls in the Newtown Creek watershed north and east of Breesport, well logs along two of the larger valleys (Newtown Creek 
and North Branch Newtown Creek) indicate that till overlies and confines stratified deposits - both fine-grained lacustrine deposits and sand and gravel (fig. 5; plate 1). Along the north side of the broad Newtown Creek valley area just southwest of Erin, three wells with till at or near land surface tap between 6 and $57 \mathrm{ft}$ of gravel at depths between 31 and $88 \mathrm{ft}$. One of these logs is included in hydrogeologic section $D-D^{\prime}$ (well CM1201; fig. 5). Within the North Branch Newtown Creek valley, sand and gravel are noted in several logs up to the divide, which indicates sediment carried by meltwater from ice to the north, outside of the watershed.

The only significant stratified surficial deposits (mixed till and ice contact and limited outwash) are along Bulkley Creek, a tributary of North Branch Newtown Creek. This creek has the lowest notched divide within the Newtown Creek watershed, which may have been another pathway of meltwater from outside of the watershed during deglaciation.

\section{Postglacial Deposits}

After retreat of ice from the study area watersheds, postglacial geomorphic processes have acted on the landscape: mass wasting of unstable deposits (mostly till) on steep slopes (fig. 4), downcutting of rivers and streams, deposition of alluvium on flood plains, and deposition of alluvial fans where high-gradient streams enter low-gradient valleys (plate 1). Alluvium in the large valleys is as much as $18 \mathrm{ft}$ thick and typically consists of fine sand and silt, with gravelly zones near the bottom of the deposits. In the Chemung River valley, alluvial gravels have been mapped, which may represent reworked outwash sand and gravel. Alluvial fan deposits may reach thicknesses of $35 \mathrm{ft}$ and are generally described as silty or poorly sorted gravels. Alluvial fans, created by deposition of sediment-laden inflows from tributaries, are most prominent in the Baldwin Creek and Wynkoop Creek valleys (plate 1). These deposits commonly deflect the valley streams to the opposite side of the valley, sometimes restricting drainage and creating wetlands. Alluvial fans deposited across the floor of notched divides can locally shift the location of the divide.

\section{Groundwater-Resource Potential of Valley-Fill Aquifers in the Study Area}

Groundwater-resource potential of valley-fill aquifers within the study area is highly variable but in most valleys is limited by narrow aquifer geometry, thin saturated thicknesses of sand and gravel, and the prevalence of till beneath the larger upland tributary valleys. Furthermore, deep wells completed in bedrock or confined sand and gravel in valleys run the risk of interesecting salty, unpotable water at depths greater than about $150 \mathrm{ft}$ below the valley floors. Limited well-log data support the idea that the depth to salty water is shallowest where groundwater flow is restricted by confining units. Salty water has been noted beneath the Newtown Creek valley at Erin, Breesport, near the junction with North Branch Newtown Creek, and along the Chemung River valley from Lowman to Chemung (fig. 7).

An overview of estimated well yields available from screened wells in the valley-fill aquifers within the study area is provided in figure 7. These estimates should be viewed as the upper limit of possible yield to properly screened, developed, and spaced wells, especially within the "low" category of yield estimates, because this category includes aquifer material up to the aquifer boundary. Estimation was hampered by the small number of screened community supply wells, the lack of subsurface data over large reaches of the valleys, and insufficient detail in some well logs. Yields from sand and gravel wells completed with open-ended well casing provide some indication of potential yield of screened wells; a conservative factor of 2 to 3 times the open-ended casing well yield was used to estimate screened well yield. Reported yields from open-ended casing wells represent drilling results that were sufficient for domestic water supply and thus do not necessarily represent the maximum possible yields. Estimates for both "moderate" and "moderate to high" potential yield categories in figure 7 are consistent with reported screened well yields.

The area of highest potential well yields is in the southern half of the Chemung River valley west of Chemung (figs. 2 and 7). The few wells that tap this aquifer indicate tens of feet of saturated sand and gravel. High well yields from this aquifer may be further enhanced where the Chemung River is nearby and can provide additional water to pumped wells; pumping stresses on the aquifer can potentially reverse local groundwater flow and subsequently induce infiltration of river water into the aquifer.

The "moderate to high" and "high" potential yield categories are limited to areas within the Chemung River valley and the lower valley reach of Newtown Creek, west of Breesport. The most favorable areas in the Chemung River valley include mapped ice-contact deposits from west of Lowman eastward to Chemung. The saturated thickness of permeable sand and gravel deposits is the key factor in whether or not these deposits are productive aquifers. The high, well-defined esker segments in this area may indicate bedrock or till at shallow depths - if so, yields will be much lower than the estimates. The western end of the ice-contact deposits (fig. 2) likely has the greatest saturated thickness and yield potential within this "moderate to high" area on figure 7, and may continue west of the study area.

The other most favorable aquifer area is in the lower Newtown Creek valley at the confluence with North Branch Newtown Creek. Confined, permeable sand and gravel support a yield of $170 \mathrm{gal} / \mathrm{min}$ from a screened supply well and yields of 20 to $50 \mathrm{gal} / \mathrm{min}$ from open-ended casing wells in this area.

The prevalence of wells completed in bedrock within the study area, as mentioned previously, merits a brief summary. Almost all upland wells tap the bedrock aquifer, which typically provides sufficient water for most domestic 


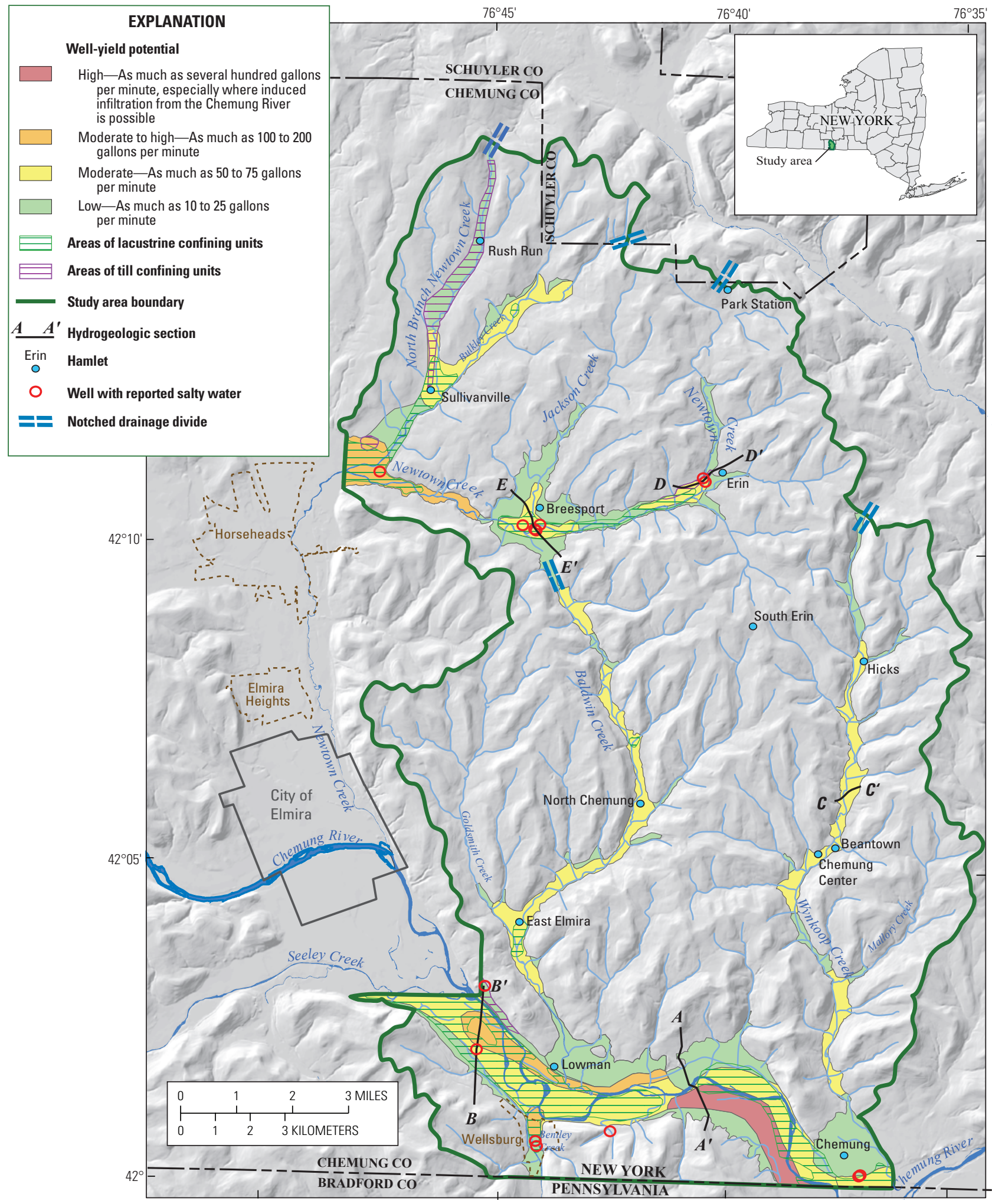

Shaded-relief base derived from U.S. Geological Survey 10 meter National Elevation Dataset,1:24,000, 2014 Universal Transverse Mercator projection, zone 18 North American Datum of 1983

Figure 7. Extent of valley-fill aquifers, confining units, and aquifer well-yield potential, eastern Chemung County, New York. 
needs. Most upland wells reportedly yield between about 4 and $20 \mathrm{gal} / \mathrm{min}$. Many years ago, domestic water supplies in upland areas came from springs or large-diameter dug wells, some of which are still in use.

Bedrock wells are also now more commonplace in valley areas than they were in the 1950s (Wetterhall, 1959). Water stored in overlying valley-fill deposits may contribute to bedrock well yield. Valley wells may be completed in bedrock where silt and fine sand in overlying unconsolidated deposits limit permeability or cause turbidity and sediment problems, but such wells risk intersecting fractures with poor water quality.

\section{Sources of Groundwater and Groundwater Flow}

Precipitation that infiltrates directly or indirectly into the subsurface (recharge) is the ultimate source of groundwater throughout the study area. Groundwater exits the flow system (1) as diffuse subsurface discharge to tributary streams in the uplands and to rivers and streams in the largest valleys; (2) as discharge from springs, where groundwater flow is directed to land surface at topographic low points or where permeable sediments such as sand and gravel overlie less pervious bedrock, till, or glaciolacustrine deposits; (3) as evapotranspiration; and (4) as groundwater flow downvalley within the Chemung River valley-fill aquifer beyond the study area.

Recharge in upland areas is entirely from precipitation. Precipitation that is not lost to evapotranspiration either flows downslope as overland flow and within macropores (frost cracks, root holes, and mole runs) in the upper few feet of weathered till, or infiltrates downward into till or bedrock. In both cases, water eventually moves down from the uplands and discharges to streams or infiltrates into permeable valleyfill deposits. Where bedrock is mantled by thin, discontinuous till, a substantial fraction of precipitation may infiltrate downward as recharge to bedrock. Much of this water flows downslope within the upper 100 to $300 \mathrm{ft}$ of fractured bedrock (fig. 8). Where several tens to hundreds of feet of till blanket bedrock, recharge to bedrock by downward infiltration is exceedingly small per unit area (Randall and Finch, 2008).

Valley-fill aquifers receive recharge from direct infiltration of precipitation into permeable glacial or alluvial deposits, but Morrissey and others (1988) documented that recharge from upland sources can exceed that of direct precipitation. Upland sources of recharge (fig. 8) include (1) groundwater flow to the valley from adjacent unchanneled hillslopes, and (2) infiltration of streamflow from tributaries as they cross alluvial fan deposits in the valley (Randall, 1978).

The Chemung River valley-fill aquifer is a composite unconfined/confined system with areas of unconfined icecontact sand and gravel that transition to confined conditions beneath adjacent lacustrine units (upvalley or downvalley from hydrogeologic sections shown in figs. 2 and 3). Confined aquifers beneath lacustrine confining units are likely present in places, but the number of well logs in the middle of the Chemung River valley is too few to delineate such aquifers. The unconfined aquifer areas receive recharge from precipitation and, if pumped, might derive additional recharge through induced infiltration from the Chemung River if there is hydraulic interconnection. Confined aquifers do not receive direct recharge from precipitation but may receive recharge along valley edges through ice-contact sand and gravel or alluvial fans (Crain, 1966) or shallow fractured bedrock. Natural groundwater flow in deep, confined valley-fill aquifer areas is exceedingly slow under natural conditions because confining units largely prevent upward discharge to streams and rivers. Groundwater withdrawals from confined aquifers would accelerate groundwater flow toward withdrawal points and induce downward flow where unconfined aquifer material is in hydraulic connection with the deep aquifer.

Groundwater flow within unconfined alluvium in the Chemung River valley (and other main valleys of eastern Chemung County) is predominantly from the valley walls toward the river/creek with a gentle downvalley component, dependent on local valley-floor gradients and topography (fig. 8). Groundwater flow is likely most rapid within this part of the aquifer system because groundwater recharge from precipitation plus inputs from hillsides and streams that traverse alluvial fans must be conveyed to the river under natural groundwater-flow conditions. Alluvial aquifers are generally too thin to support groundwater withdrawals.

Modest aquifers in the narrow Baldwin Creek and Wynkoop Creek valleys (fig. 4) appear largely unconfined and therefore receive substantial recharge, whereas those in the Newtown Creek at Erin (fig. 5) and within the North Branch Newtown Creek valley are confined by till and likely have limited recharge and water-resource potential. The aquifer at the junction of Newtown Creek and North Branch Newtown Creek is partly confined and thus has intermediate potential for recharge.

\section{Considerations for Aquifer Protection}

Aquifer protection in the study area is a topic of public concern in relation to the potential for high-volume hydraulicfracturing natural gas drilling in this part of New York. Also, the presence of two landfills on, or adjacent to, valleybottom ice-contact deposits in the Chemung River valley is a potential water-quality concern (fig. 2; plate 1). Potential sustainable-yield estimates for valley-fill aquifers in this report (fig. 7) provide managers with a basis for prioritizing aquifer protection efforts. 


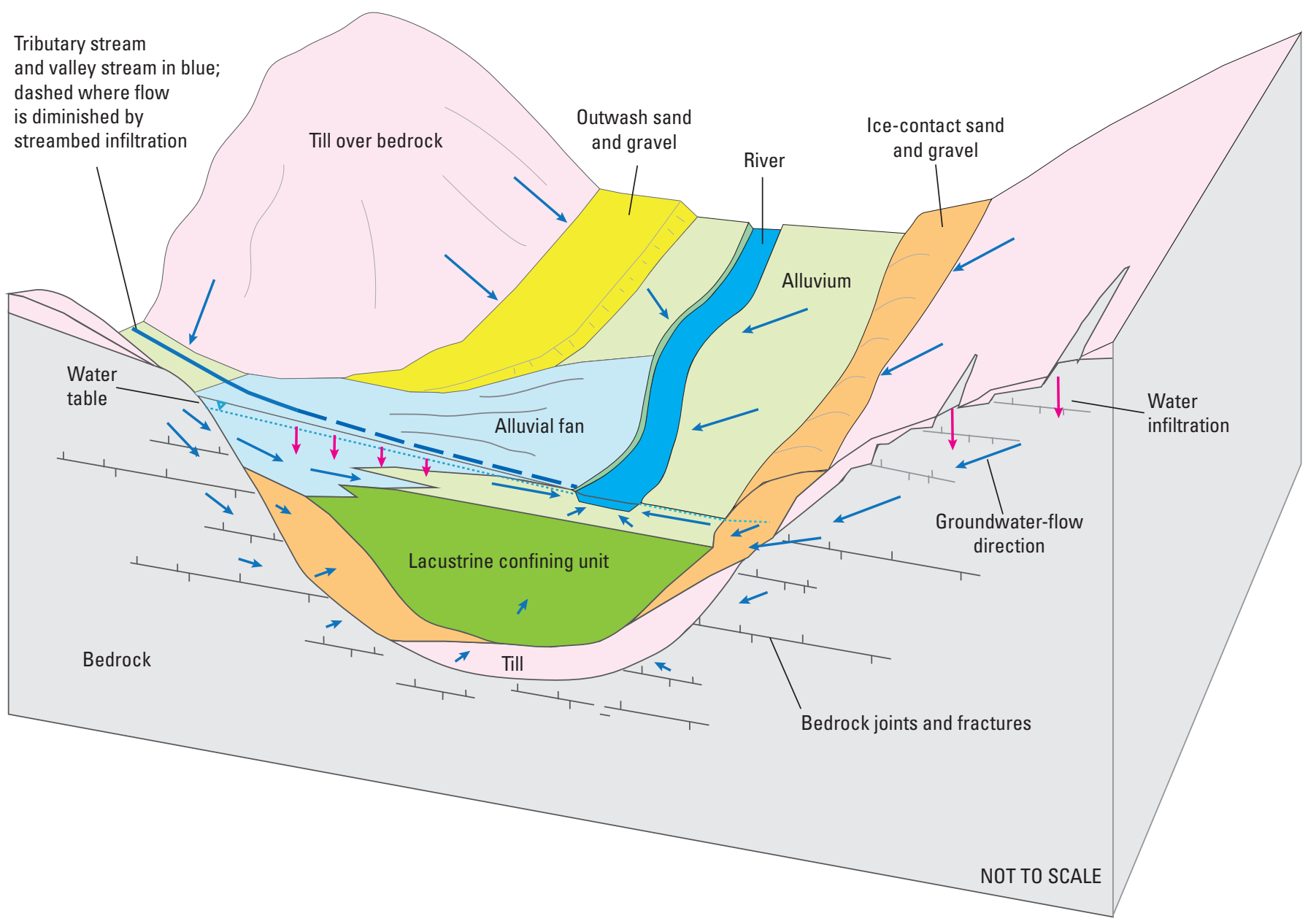

Figure 8. Conceptual block diagram of groundwater flow in a valley underlain by fine-grained lacustrine deposits in the dissected Appalachian Plateau area of south-central New York State.

\section{Upland Watersheds That Contribute Water to Valley-Fill Aquifers}

As discussed in the section "Sources of Groundwater and Groundwater Flow," infiltration (loss) of stream water as tributary streams cross alluvial fans in the main valleys is a source of recharge to the valley aquifers. If water quality in those streams is compromised by activities in the upland watershed, groundwater quality in the valley may, in turn, be degraded; therefore, the maintenance of good water quality in the upland watersheds that are the source of these streams is an important consideration for protection of the valley-fill aquifer system. Unchanneled hillsides adjacent to the valleys also provide recharge to the valley-fill aquifers through surface runoff or subsurface flow that seeps into the aquifer along the edges of the valley (fig. 8).

\section{Upland Areas of Thin Till over Bedrock}

Groundwater in bedrock in upland areas is far more susceptible to contamination in areas with thin till or exposed bedrock than where till is greater than $50 \mathrm{ft}$ thick. Contamination in these areas with thin till would migrate downslope through shallow fractures in the upper 100 to $300 \mathrm{ft}$ of bedrock; therefore, avoidance of activities that could potentially degrade groundwater quality in areas of thin till or exposed bedrock (plate 1) in favor of areas with thick till can minimize adverse effects on nearby and downgradient domestic wells. 


\section{Summary}

The extent, hydrogeologic framework, and potential well yields of valley-fill aquifers within a 151-square-mile area of eastern Chemung County, New York, were investigated by the U.S. Geological Survey, in cooperation with the New York State Department of Environmental Conservation, and the upland till distribution over bedrock was characterized. The hydrogeologic framework of valley-fill aquifers was interpreted from multiple sources of surficial and subsurface data and an interpretation of the origin of the glacial deposits, particularly during retreat of glacial ice from the region.

This information provides a foundation for wellhead protection programs, water-resource management and planning decisions, and groundwater remediation in the study area. The study area has undergone natural-gas resource development with conventional gas wells and is underlain by the Marcellus Shale and Utica Shale, which are unconventional sources of natural gas. Therefore, aquifer mapping and a basic understanding of sources of water that replenish the aquifers, along with current [2014] waterresource use, was warranted for management and protection of local water resources.

Current water-resource development in the region is mostly in the form of domestic wells. Most domestic wells in upland areas tap the fractured-bedrock aquifer. Domestic wells in the Chemung River valley and large tributary valleys may tap sand and gravel deposits with open-ended well casings or may be completed as bedrock wells that are cased through the valley-fill deposits. Existing community supplies that utilize screened production wells that tap sand and gravel deposits have maximum reported yields of 50 to 170 gallons per minute.

Potential yields from valley-fill aquifers are greatest in areas of saturated sand and gravel in the Chemung River valley, especially where induced infiltration of additional water is possible from the Chemung River, along the south side of the valley about 1.5 miles west of Chemung, N.Y. The second most favorable area is the Newtown Creek valley near its confluence with North Branch Newtown Creek east of Horseheads, N.Y. Extensive surficial sand and gravel deposits in and around Breesport, N.Y., are largely unsaturated, but may be more saturated along the east side of Jackson Creek immediately north of Breesport. Till deposits confine sand and gravel along Newtown Creek at Erin, N.Y., and along much of the upper reach of North Branch Newtown Creek; this confining unit may limit recharge and potential well yield. The north-south oriented valleys of Baldwin and Wynkoop Creeks are relatively narrow but contain variably sorted sand and gravel that can support modest community water-supply needs.

Protection of groundwater quality in valley-fill aquifers of the study area should consider not only aquifer extent but also upland areas that contribute recharge to these aquifers, such as adjacent hillsides that drain directly to the valleys and the watersheds of tributary streams that lose water to the aquifers upon entering valleys. Protection of water resources in upland areas from activities that may compromise groundwater quality is most important where till is thin over bedrock or where bedrock crops out at land surface.

\section{References Cited}

Barton and Loguidice, D.P.C., 2014, Chemung County landfill, Chemung County, New York-Hydrogeologic investigation report: Syracuse, N.Y., Barton and Loguidice, D.P.C., 945 p.

Coates, D.R., 1966, Glaciated Appalachian Plateau-Till shadows on hills: Science, v. 152, p. 1617-1619.

Coates, D.R., 1981, Geomorphology of south-central New York, in Enos, Paul, ed., Guidebook for field trips in southcentral New York: Binghamton, New York State Geological Association, 53rd Annual Meeting field-trip guidebook, p. 171-200.

Crain, L.J., 1966, Ground-water resources of the Jamestown area, New York, with emphasis on the hydrology of the major stream valleys: New York State Water Resources Commission Bulletin 58, $167 \mathrm{p}$.

Denny, C.S., and Lyford, W.H., 1963, Surficial geology and soils of the Elmira-Williamsport region, New York and Pennsylvania: U.S. Geological Survey Professional Paper 379, 60 p., 6 pls.

Elmira Water Board, 2015, Annual drinking water quality report-2014: Elmira Water Board report, 2 p., accessed March 15, 2015, at http://www.elmirawaterboard.org/pdf/ awqr.pdf.

Fairchild, H.L., 1932, New York Moraines: Geological Society of American Bulletin, v. 43, no. 3, p. 627-662.

Gillespie, R.H., Jr., 1980, Quaternary geology of south-central New York: Binghamton, New York, State University of New York, unpublished Ph.D. thesis, 205 p.

Heisig, P.M., 1999, Water resources of the Batavia Kill Basin at Windham, Greene County, New York: U.S. Geological Survey Water-Resources Investigations Report 98-4036, $96 \mathrm{p}$.

Hollyday, E.F., 1969, An appraisal of the ground-water resources of the Susquehanna River Basin in New York State: U.S. Geological Survey Open-File Report 69-128, $97 \mathrm{p} ., 1 \mathrm{pl}$.

Isachsen, Y.W., and McKendree, W., 1977, Preliminary brittle structure map of New York: New York State Museum Map and Chart Series no. 31D, Niagara—Finger Lakes sheet, scale 1:250,000. 
Jacobi, R.D., 2002, Basement faults and seismicity in the Appalachian Basin of New York State: Tectonophysics, v. 353, p. $75-113$.

King, C.A.M., and Coates, D.R., 1973, Glacio-periglacial landforms within the Susquehanna-Great Bend area of New York and Pennsylvania: Quaternary Research, v. 3, p. 600-620.

Lash, G., Loewy, S., and Engelder, T., 2004, Preferential jointing of Upper Devonian black shale, Appalachian Plateau, USA-Evidence supporting hydrocarbon generation as a joint driving mechanism, in Cosgrove, J.W., and Engelder, T., eds., The initiation, propagation, and arrest of joints and other fractures: London, Geological Society, Special Publication 231, p. 129-151.

MacNish, R.D., and Randall, A.D., 1982, Stratified-drift aquifers in the Susquehanna River Basin, New York: New York State Department of Environmental Conservation Bulletin 75, 68 p.

Marcellus Center for Outreach and Research, 2015, Maps and graphics: Pennsylvania State University Marcellus Center for Outreach and Research Web site, accessed May 1, 2015, at http://www.marcellus.psu.edu/resources/maps.php.

McGhee Jr., G.R., and Sutton, R.G., 1985, Late Devonian marine ecosystems of the lower West Falls Group in New York, in Woodrow, D.L., and Sevon, W.D., eds., The Catskill delta: Geological Society of America Special Paper 201, p. 199-209.

Miller, T.S., Randall, A.D., Belli, J.L., and Allen, R.V., 1982, Geohydrology of the valley-fill aquifer in the Elmira area, Chemung County, New York: U.S. Geological Survey Open-File Report 82-110, 7 sheets, scale 1:24,000.

Morrissey, D.J., Randall, A.D., and Williams, J.H., 1988, Upland runoff as a major source of recharge to stratified drift in the glaciated northeast, in Randall, A.D., and Johnson, A.I., eds., Regional Aquifer systems of the United States-The northeast glacial aquifers: American Water Resources Association Monograph Series no. 11, p. 17-36.

Muller, E.H., and Cadwell, D.H., 1986, Surficial geologic map of New York-Finger Lakes sheet: New York State Museum Geological Survey, Map and Chart Series no. 40, scale 1:250,000.

New York State Museum, 2014, Empire State Oil and Gas Information System: Empire State Oil and Gas Information System database, accessed March 11, 2014, at http://esogis.nysm.nysed.gov/.

Pearson, C.S., Parsons, R.A., Hulbert, N.B., Jr., and Williams, W.C., 1973, Soil Survey of Chemung County, New York: United States Department of Agriculture, Soil Conservation Service, 100 p., 34 pl.
Randall, A.D., 1972, Records of wells and test borings in the Susquehanna River Basin, New York: New York State Department of Environmental Conservation Bulletin 69, $92 \mathrm{p}$.

Randall, A.D., 1978, Infiltration from tributary streams in the Susquehanna River Basin: U.S. Geological Survey Journal of Research, v. 6, no. 3, p. 285-297.

Randall, A.D., 2001, Hydrogeologic framework of stratifieddrift aquifers in the glaciated northeastern United States: U.S. Geological Survey Professional Paper 1415-B, 179 p., $1 \mathrm{pl}$.

Randall, A.D., and Finch, Anne, 2008, Recharge to shale bedrock at Averill Park, an upland hamlet in eastern New York-An estimate based on pumpage within a defined cone of depression: U.S. Geological Survey Scientific Investigations Report 2008-5087, 78 p.

Reynolds, R.J., 2003, Hydrogeology of the Waverly-Sayre area in Tioga and Chemung Counties, New York and Bradford County, Pennsylvania: U.S. Geological Survey Open-File Report 02-284, 6 sheets, scale 1:24,000, 1 CD-ROM.

Rickard, L.V., and Fisher, D.W., 1970, Geologic map of New York, Finger Lakes sheet: New York State Museum and Science Service, Map and Chart Series no. 15, scale $1: 250,000$.

U.S. Department of Agriculture, 2008, Soil Survey Geographic (SSURGO) database for Chemung County, New York: SSURGO database, accessed January 15, 2014, at http://soildatamart.nrcs.usda.gov.

U.S. Environmental Protection Agency, n.d., Safe drinking water search for the State of New York: EPA Safe Drinking Water Information System (SDWIS) database: accessed November 14, 2013, at http://oaspub.epa.gov/enviro/ sdw_form_v2.create_page?state_abbr=NY.

U.S. Geological Survey, 2001, National Water Information System (NWISWeb): U.S. Geological Survey database, accessed October 5, 2012, at http://waterdata.usgs.gov/ nwis/.

USA.com, 2012, Chemung county: USA.com Web site, accessed April 4, 2014, at http:/www.usa.com/chemungcounty-ny.htm.

Wedel, A.A., 1932, Geologic structure of the Devonian strata of south-central New York: New York State Museum Bulletin no. 294, 74 p., 1 pl.

Wetterhall, W.S., 1959, The ground water resources of Chemung County, New York: New York Water Power and Control Commission Bulletin GW-40, 58 p. 
Williams, H.S., Tarr, R.S., and Kindle, E.M., 1909,

Description of the Watkins Glen-Catatonk district, New

York: U.S. Geological Survey Geologic Atlas, Folio 169, 33 p., 6 pls.

Williams, J.H., 1991, Tributary-stream infiltration in Marsh

Creek Valley, north-central Pennsylvania: U.S. Geological

Survey Water-Resources Investigations Report 90-4052,

$39 \mathrm{p}$.

YEC, Inc., 1991, Engineering investigations at inactive hazardous waste sites in the state of New York, phase 2 investigation-Jilson's, Ashland, New York, Chemung County, NYSDEC I.D. NO. 808003: Valley Cottage, N.Y., YEC, Inc. [variously paged]. 


\section{Appendix 1. Well Data for Eastern Chemung County, New York}

[Available separately for download at http://dx.doi.org/10.3133/sir20155092] 
For additional information write to:

Director, New York Water Science Center

U.S. Geological Survey

425 Jordan Road

Troy, NY 12180-8349

dc_ny@usgs.gov

Information requests:

(518) 285-5602

or visit our Web site at:

http://ny.water.usgs.gov

Publishing support by:

The Pembroke Publishing Service Center. 
